\title{
ANALISIS PENERAPAN PROGRAM KESELAMATAN PASIEN DI PUSKESMAS
}

\author{
SRI HARVITA SARI MARPAUNG/181101125
}

\author{
$\underline{\text { Sriharvitaaasm11@gmail.com }}$
}

\begin{abstract}
ABSTRAK
Keselamatan pasien merupakan prioritas dan tanggung jawab para pemberi layanan kesehatan dan juga fasilitas kesehatan baik dari tingkat pertama sampai tingkat akhir, penerapan keselamatan pasien harus menjadi prioritas utama dalam memberikan layanan kesehatan. Tujuan dari penerapan program keselamatan pasien adalah untuk meningkatkan derajat kesehatan pasien dan meningkatkan rasa aman dan nyaman pada pasien. Dalam penerapannya dapat dilakukan dengan meningkatkan kesadaran diri kesadaran diri akan nilai keselamatan pasien, berbagi pengalaman, kebijakan fasilitas kesehatan, menerapkan lima prinsip keselamatan pasien, dan enam sasaran keselamatan pasien. Perawat sebagai pemberi asuhan keperawatan memiliki tanggung jawab besar dalam menjamin keselamatan pasien.
\end{abstract}

Kata kunci : keselamatan pasien, perawat, fasilitas kesehatan pertama(puskesmas).

\section{LATAR BELAKANG}

Keselamatan pasien merupakan salah satu program yang diutamakan oleh pemberi layanan kesehatan baik dari profesi yang memberikan layanan kesehatan maupun tempat/penyedia layanan kesehatan seperti rumah sakit, puskesmas, praktik klinik dan lainnya. Sebagai penerima pelayanan kesehatan masyarakat memiliki hak untuk memilih fasilitas kesehatan salah satunya fasilitas kesehatan tingkat pertama yang sesuai dengan kebutuhan pasien/klien. Puskesmas sebagai fasilitas kesehatan pertama yang berfungsi sebagai penapis rujukan harus dapat memberikan layanan kesehatan yang berkualitas sesuai dengan standar pelayanan maupun standar kompetensi sehingga dapat menjamin kesehatan dan keselamatan pasien. Keselamatan pasien merupakan prioritas utama untuk dilaksanakan karena terkait dengan isu mutu pelayanan dan citra puskesmas tersebut.

Menurut Institude of Medicine (1999) keselamatan pasien (patient safety) didefenisikan sebagai freedom from accidential injury yang disebabkan oleh kesalahan yang meliputi kegagalan suatu perencanaan atau perencanaan salah yang telah digunakan untuk 
mencapai tujuan. Perawat sebagai pemberi layanan kesehatan memiliki peranan yang sangat penting dalam proses perawatan pasien, peran utama yang dimiliki oleh perawat adalah meningkatkan dan mempertahankan kesehatan pasien, membantu pasien dalam memberikan pengertian tentang proses perawatan yang sedang dijalani oleh pasien, serta ikut andil dalam pengambilan keputusan tentang perawatan apa yang akan diberikan kepada pasien gua meningkatkan drajat kesehatan pasien.

Pengelolan keselamatan pasien dalam pelayanan di puskesmas berguna untuk mengurangi tingkat kecacatan atau kesalahan dalam memberikan layanan kesehatan. Terjadinya insiden keselamatan pasien di puskesmas akan memberi dampak yang buruk bagi pasien, staf puskesmas, dan puskesmas itu sendiri. Rendahnya kualitas atau mutu asuhan yang diberikan karena keselamatan pasien merupakan bagian dari mutu (Flyn, 2002 dalam Cahyono, 2008).

\section{TUJUAN}

Tujuan dari penulisan ini adalah untuk menganalisis penerapan progran keselamatan pasien di puskesmas yang diberikan dalam bentuk layanan bertujuan untuk meningkatkan kualitas pelayanan dan meningkatkan derajat kesehatan pasien.

\section{METODE}

Metode yang digunakan pada penulisan ini adalah literature riview berdasarkan text book, jurnal, $e$ - book (10 tahun terakhir) dengan cara menganalisis, eksplorasi sumber, dan kajian bebas.

\section{HASIL}

Hasil yang diperoleh dari literature review ini adalah mengetahui penerapan program keselamatan pasien di puskesmas telah dilaksanakan dengan baik dengan tujuan memberikan keamanan bagi pasien yang dapat meningkatkan derajat kesehatan pasien.

\section{PEMBAHASAN}

Keselamatan pasien (patient safety) merupakan salah satu program utama dalam memberikan layanan kesehatan, tim medis termasuk perawat harus dapat mengutamakan keselamatan pasien. Salah satu penerapan program keselamatan pasien pada fasilitas kesehatan yaitu puskesmas sebagai tingkat pertama fasilitas kesehatan yang juga berperan sebagai pemberi 
rujukan/petunjuk kepada pasien ke rumah sakit mana pasien akan pergi yang telah disesuaikan dengan kebutuhan pasien.

Dalam memberikan layanan kesehatan di puskesmas perawat harus memiliki kemampuan dalam memberikan asuhan yang berkualitas dan dapat membantu pasien untuk meningkatkan derajat kesehatan pasien alah satu yang utama adalah keselamatan pasien itu sendiri. Perawat sebelum melakukan suatu tindakan harus terlebih dahulu memikirkan apa manfaat tindakan dan apa masalah yang dapat ditimbulkan oleh tindakan tersebut, hal ini dilakukan untuk meningkatkan keselamatan pasien sehingga selama berada di dalam puskesmas baik dalam masa rawat inap maupun yang lainnya pasien dapat menerima layanan kesehatan yang berkualita serta dapat memberikan rasa aman dan nyaman selama masa perawatan/pengobatan.

Dalam menerapkan program keselamatan pasien di puskesmas ada beberapa hal yang dapat dilakukan oleh pemberi layanan kesehatan maupun fasilitas kesehatan seperti :

1. Meningkatkan kesadaran diri kesadaran diri akan nilai keselamatan pasien, ciptakan kepemimpinan dan budaya yang terbuka dan adil bagi semua orng yang berada di lingkup fasilitas kesehatan maupun masyarakat.

2. Saling mendukung baik pemimpin kepada staf begitu juga sebaliknya.

3. Belajar dan berbagi pengalaman tentang keselamatan pasien seperti berbagi pengalaman untuk melakukan analisa akar masalah mengapa kejadian/masalah itu bisa terjadi.

4. Mencegah cedera melalui implementasi sistem keselamatan pasien dengan menggunakan informasi yang ada tentang kejadian atau masalah untuk melakukan perubahan pada sistem pelayanan.

5. Pada fasilitas kesehatan pimpinan dapat mengeluarkan kebijakan seperti pembuatan standar untuk profesi kesehatan baik untuk dokter, perawat, apoteker, dan tim medis lainnya.

Dalam menerapkan program keselamatan paien di puskesmas dapat dilakukan dengan menerapkan lima prinsip keselamatan pasien yaitu : 
Provide leadership meliputi :

1. Menjadikan keselatan pasien sebagai tujuan utma/prioritas.

2. Menjadikan keselamatan pasien sebagai tanggung jawab bersama.

3. Menunjuk/menugaskan seseorang yang bertanggung jawab untuk progran keselamatan.

4. Menyediakan sumber daya manusia dan dana untuk analisis error dan redesign sistem.

5. Mengembangkan mekanisme yang efektif untuk mengidentifikasi "unsafe" dokter.

\section{Memperhatikan keterbatasan manusia dalam perancangan proses}

1. Menyederhanakan proses

2. Membuat standar proses

\section{Antisipasi untuk kejadian tak terduga}

1. Pendekatan proaktif

2. Menyediakan antidotum

3. Training simulasi

\section{Menciptakan atmosfer "Learning"}

Penerapan enam sasaran keselamatan pasien juga dapat dilakukan untuk meningkatkan keselamatan pasien di puskesmas seperti :

1. Ketepatan identifikasi pasien

2. Peningkatan komunikasi yang efektif

3. Peningkatan keamanan obat yang perlu diwaspadai (high alert)
4. Kepastian tepat lokasi, tepat prosedur, tepat pasca operasi

5. Pengurangan risiko infeksi terksit pelayanan kesehatan

6. Pengurangan risiko jatuh

Perawat sebagai pemberi asuhan dituntut harus dapat memberikan asuhan keperawatan yang bermutu, dikarenakan perawat merupakaan profesi yang difokuskan pada perawatan individu, keluarga dan masyarakat sehingga perawat dapat mencapai, mempertahankan, atau memulihkan kesehatan yang optimal dan kualitas hidup dari lahir sampai mati (Wales, 2010). Dalam hal ini perawat merupakan pemberi layanan kesehatan yang memiliki tanggung jawab besar terhadap keselmatan pasien di fasilitas kesehatan manapun.

\section{KESIMPULAN}

Keselamatan pasien merupakan prioritas utama bagi pemberi layanan kesehatan dan juga fasilitas kesehatan seperti rumah sakit, puskesmas, praktik klinik dan fasilitas kesehatan lainnya. Dalam penerapannya dapat dilakukan dengan menerapkan lima prinsip keselamatan pasien, dan enam sasaran keselamatan pasien, serta dapat dilakukan dengan menerapkan kesadaran pada diri sendiri untuk meningkatkan derajat kesehatan dan keselamatan pasien yang ditangani. Perawat sebagai pemberi asuhan keperawatan bertanggung jawab besar dalam membantu memenuhi kebutuhan pasien salah satunya rasa aman dan nyaman. 


\section{REFERENSI}

Anggraini, A. N. Dkk. (2018).

Hubungan Implementasi IPSG

(International Patient Safety Goals)

dengan Kepuasan Pasien di Puskesmas

Kasihan I Bantul. (Indonesian Journal of Hospital Administration), Vol. 1, No.

1, Tahun 2018.

Azrul, A. (1996). Menuju Pelayanan

Kesehatan yang Bermutu. Jakarta:

Salemba Medika.

Asmadi. (2008). Konsep Dasar

Keperawatan. Jakarta : EGC

Cahyono, J. B. S. (2012). Membangun

Budaya Keselamatan Pasien dalam

Praktek Kedokteran. Yogyakarta

Deswani. (2009). Proses Keperawatan dan Berpikir Kritis. Jakarta : Salemba Medika

Departemen Kesehatan RI. (2006).

Panduan Nasional Keselamatan Pasien

Rumah sakit. Jakarta : Depkes RI

Gede, M. A. A. (2011). Manajemen

Mutu Pelayanan Kesehatan. Jakarta :

EGC

Harus, B. D. (2015). Pengetahuan

Perawat tentang Keselamatan Pasien

dengan Pelaksanaan Prosedur

Keselamatan Pasien Rumah Sakit
(KPRS) di Rumah Sakit Panti Waluya

Sawahan Malang. (Jurnal CARE), Vol.

3, No. 1, Tahun 2015.

Kemenkes RI. (2013). Panduan

Keselamatan Pasien. Jakarta

Marquis, B.L. (2010). Kepemimpinan dan Manajemen Keperawatan: Teori dan Aplikasi. Jakarta : EGC

Nursalam. (2011). Manajemen

Keperawatan: Aplikasi dalam Keperawatan Profesional, ed.3. Jakarta : Salemba Medika.

Perry \& Potter. (2005). Fundamental Keperawatan : Konsep Proses dan Praktek. Jakarta : EGC

Rivai F, Sidin A.I, Kartika I. (2016). Faktor yang Berhubungan dengan ImplementasinKeslamatan Pasien di RSUD Ajjappannge Soppeng Tahun 2015. Volume 05

Simamora, R.H. (2018). Buku Ajar Keselamatan Pasien Melalui Timbang Terima Pasien Berbasis Komunikasi Efektif: SBAR

Stanley, M. (2006). Buku Ajar Keperawatan Gerontik. Edisi 2. Jakarta: EGC 
Tutiani. Dkk. (2017). Manajemen

Keselamatan Pasien. Jakarta

Yulia, S. Dkk . (2012). Peningkatan

Pemahaman Perawat Pelaksana dalam
Penerapan Keselamatan Pasien Melalui Pelatihan Keselamatan Pasien. (Jurnal Keperawatan), Vol. 15, No. 3, Tahun 2012 ; Hal 185 - 192. 